\title{
STUDI PEMBUATAN PETA INFORMASI BIDANG TANAH (PIBT) DENGAN PARTISIPASI MASYARAKAT MENGGUNAKAN PETA DASAR DARI PEMETAAN FOTOGRAMETRI METODE FOTO FORMAT KECIL
}

\author{
Yanto Budisusanto, Anggoro Wahyu Widodo, Agung Budi Cahyono \\ Departemen Teknik Geomatika, Fakultas Teknik Sipil Lingkungan dan Kebumian \\ Institut Teknologi Sepuluh Nopember (ITS) \\ JI. Raya ITS, Keputih, Sukolilo, Kota SBY, Jawa Timur 60111 \\ e-mail:yanto_b@geodesy.its.ac.id
}

\begin{abstract}
Abstrak
Peta Informasi Bidang Tanah (PIBT) merupakan peta hasil dari kegiatan pemetaan bidang tanah melalui partisipasi masyarakat dalam pengumpulan datanya (Direktur Jenderal Infrastruktur Keagrariaan, 2017). Peta ini berisi informasi mengenai 1 (satu) atau lebih bidang tanah yang memuat posisi bidang tanah dan informasi yang terkait dengan bidang tanah tersebut beserta nama pemiliknya atau subyek yang menguasai bidang tanah tersebut. Dalam pembuatan peta informasi bidang tanah ini dilakukan dengan menggunakan peta dasar yang didapatkan melalui proses pemetaan secara fotogrametri dengan metode foto format kecil. Pemotretan menggunakan wahana drone jenis quadcopter. Pada citra foto udara format kecil (orthophoto), RMS Error menunjukkan nilai pergeseran pada proses georeferencing sebesar 4,671 cm. Untuk uji akurasi planimetrik dihasilkan RMS Error sebesar 0,099 m dan pada uji CE90 memiliki ketelitian 1:1000 setara dengan akurasi peta kelas 1. Penggalian/perolehan informasi mengenai data pertanahan dilakukan dengan melibatkan partisipasi masyarakat desa setempat (pemetaan partisipatif) sebagai sumber data. Dari hasil PIBT diketahui bahwa Desa Pojok didominasi oleh areal persawahan (bidang tanah sawah) dengan total luas 128,597 hektar yang terdiri dari bidang tanah sebanyak 615 bidang dan daerah pemukiman (bidang tanah pekarangan) dengan total luas 69,378 hektar yang terdiri dari 1.443 bidang.
\end{abstract}

Kata kunci : Bidang Tanah, Fotogrametri, Pemetaan Partisipatif, PIBT

\begin{abstract}
Land Information Map (PIBT) is a map of the results of land mapping activities through community participation in data collection. This map contains information on 1 (one) or more land parcels containing the position of land parcels and information about the landd parcels and the names of the owners or subjects who control the land parcels. In developing land information map is done with the basic map obtained through mapping photogrammetry with small format photograph method using the quadcopter UAV. On the base map (orthophoto), RMS Error value shift in the georeferencing process of $4.671 \mathrm{~cm}$. For the accuracy test planimetrik produced RMSEr of $0.099 \mathrm{~m}$ and on the CE9O test has a precision of 1: 1000 class 1. The information about land data conducted with local village communities (participatory mapping). From the PIBT results it is known that the village of Pojok is dominated by rice field area with total area of 128.597 hectares consisting of 615 fields of land parcels and residential area (parcels of yard) with a total area of 69,378 hectares consisting of 1,443 land parcels.
\end{abstract}

Keywords : Land Parcel, participatory mapping, Photogrammetry, PIBT

\section{PENDAHULUAN}

Peta Informasi Bidang Tanah (PIBT) merupakan peta hasil dari kegiatan pemetaan bidang tanah melalui partisipasi masyarakat dalam pengumpulan datanya. Peta ini berisi informasi mengenai 1 (satu) atau lebih bidang tanah yang memuat posisi bidang tanah dan informasi tentang bidang tanah tersebut beserta nama pemiliknya atau subyek yang menguasai bidang tanah tersebut. Informasi dalam peta informasi bidang tanah ini dapat dimanfaatkan untuk penyusunan kebijakan pertanahan dan ruang. Kebijakan pertanahan dan ruang ini seperti perkiraan jumlah bidang dalam 1 (satu) wilayah administrasi desa/kelurahan yang selanjutnya 
dapat dimanfaatkan untuk menunjang program pendaftaran tanah sistematis lengkap (PTSL).

Seperti yang diungkapkan oleh Sofyan Djalil (Menteri ATR/BPN) pada tahun 2016 tentang bidang tanah di Indonesia yang diperkirakan mencapai 130 juta bidang, namun baru sekitar $35 \%$ atau 45 juta yang memiliki sertifikat atau terdaftar (Ramadhiani, 2016). PIBT ini diharapkan akan membantu dalam proses pendaftaran tanah.

Pada pembuatan PIBT ini dapat digunakan peta dasar dari citra satelit resolusi tinggi maupun dengan didapatkan melalui pemetaan secara fotogrametris metode foto format kecil. Sesuai dengan petunjuk teknis pembuatan peta informasi bidang tanah melalui partisipasi masyarakat yang disusun oleh Direktur Jenderal Infrastruktur Keagrariaan pada tahun 2017 yang menyatakan dengan perkembangan teknologi penginderaan jauh dan fotogrametri, saat ini telah tersedia berbagai alat pendukung dalam kegiatan pembuatan PIBT Lengkap antara lain berupa Citra Satelit Resolusi Tinggi (CSRT), foto udara dengan wahana pesawat, foto udara dengan menggunakan wahana Unmanned Aerial Vehicle (UAV)/drone, dan lain sebagainya.

Pada penelitian ini akan dilakukan pembuatan peta informasi bidang tanah dengan peta dasar yang didapatkan melalui pemetaan secara fotogrametri dengan metode foto format kecil menggunakan Wahana quadcopter / drone. Agar data yang diperoleh lengkap, proses identifikasi dan validasi batas bidang tanah dilakukan secara kolaboratif dengan partisipasi aktif masyarakat, pemerintah daerah atau stake holders lainnya. Dengan melakukan pemetaan partisipatif, masyarakat dapat menjadi kontrol satu bidang dengan bidang lainnya yang bersebelahan sehingga potensi terjadinya konflik pertanahan akibat sengketa batas atau sengketa kepemilikan bidang tanah yang diakibatkan oleh adanya kesalahan meletakan/plotting bidang tanah dapat diminimalkan.

\section{METODE}

\section{A. Lokasi Penelitian}

Lokasi daerah penelitian berada pada Desa Pojok, Kec. Tawangsari, Kab. Sukoharjo. Desa Pojok terletak di $7^{\circ} 42^{\prime} 24^{\prime \prime}$ LS- $7^{\circ} 48^{\prime} 39^{\prime \prime}$ LS dan $110^{\circ} 47^{\prime} 32^{\prime \prime}$ BT- $110^{\circ} 48^{\prime} 28^{\prime \prime}$ BT. Berikut merupakan wilayah administrasi Desa Pojok, Kec. Tawangsari, Kab. Sukoharjo:

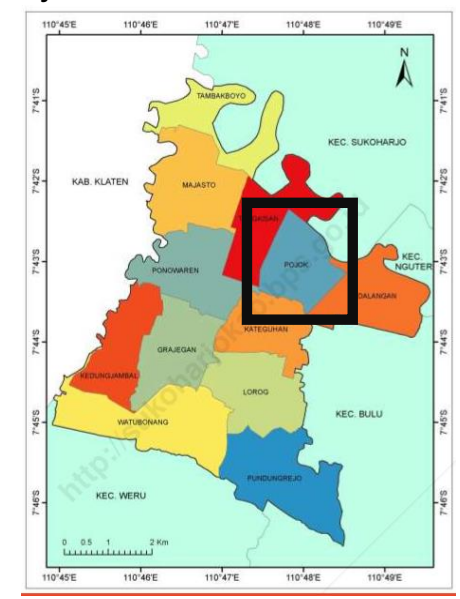

Gambar 1. Lokasi Penelitian di Desa Pojok Kecamatan Tawangsari, Kabupaten Sukoharjo, Jawa Tengah ${ }^{[2]}$

Data yang dibutuhkan dalam penelitian ini diperoleh dari:

1. Peta orthophoto sebagai peta dasar dalam pembuatan peta informasi bidang tanah. Data tersebut terdiri dari data pemotretan udara menggunakan wahana QuadCopter / drone Dji Phantom 3 Advanced serta pengukuran GPS dengan GPS Geodetik Topcon Hiperpro untuk kontrol tanah/Ground Control Point (GCP) dan titik cek/Independent Check Point (ICP) untuk uji akurasi petanya.

2. Pemetaan partisipatif dengan masyarakat / pemerintah daerah dalam proses identifikasi dan validasi batas bidang tanah.

Penelitian ini menggunakan software pengolahan foto udara, dan perangkat lunak Sistem Informasi Geografis (SIG) dalam pengolahan dan pembuatan Peta Informasi Bidang Tanah.

Tahapan pengolahan data pada penelitian ini adalah sebagai berikut:

1. Perizinan dan Persiapan

Disini dilakukan perizinan untuk melakukan penelitian dilokasi karena berhubungan dengan data pertanahan dan melibatkan masyarakat/pemerintah daerah. Persiapan disini yaitu dalam pembuatan rencana jalur terbang drone dan sebaran kontrol tanah/Ground Control Point (GCP) serta titiktitik cek/Independent Check Point (ICP).

2. Pengukuran GCP

Pengukuran Ground Control Point (GCP) menggunakan GPS tipe Geodetik untuk mendapatkan nilai dari koordinat tanah. 
3. Pemotretan Udara

Tahap ini yaitu akuisisi foto udara menggunakan wahana QuadCopter / drone Dji Phantom 3 Advanced yang dilakukan untuk mendapatkan data foto dari lokasi penelitian.

4. Orthorektifikasi

Merupakan tahapan georeferencing menggunakan data koordinat GCP hasil pengukuran GPS dengan cara rektifikasi foto objek pada model.

5. Pengolahan Foto Udara (Pembuatan Orthophoto)

Tahapan pembuatan orthophoto yaitu meliputi:

- Alignment foto

- Pemodelan geometri

- Pembentukan Tekstur 3D

- Transformasi koordinat 3D

- Orthomosaik

6. Pengumpulan Subjek/Objek dan Validasi Batas Bidang Tanah Melalui Partisipasi Masyarakat

Pada tahapan ini disebut juga dengan pemetaan partisipatif, dimana dilakukan penggalian informasi mengenai subjek/objek bidang tanah. Subjek disini berarti pemilik/penguasa dari bidang tanah tersebut, bisa perseorangan maupun badan hukum. Sedangkan objek adalah bidangbidang tanah yang dipunyai dengan hak milik, hak guna usaha, hak guna bangunan dan hak pakai, tanah hak pengelolaan, tanah wakaf maupun yang belum terdaftarkan.

Pada tahapan ini masyarakat memiliki peranan penting dalam pengumpulan data. Karena masyarakat setempat, terutama didaerah pedesaan akan mengetahui secara persis mengenai bidang tanah didaerahnya. Masyarakat disini bisa dengan warga setempat maupun dengan perangkat desa. Kemudian dilakukan identifikasi batas-batas bidang tanah baik secara langsung di atas hardcopy dari peta dasar orthophoto yang telah didapatkan maupun di komputer menyesuaikan kondisi lapangan. Setelah dilakukannya identifikasi maka dilakukan deliniasi bidang-bidang tanah tersebut serta pendataan subjek dari bidang tanahnya.

7. Digitasi dan Pembuatan Peta Informasi Bidang Tanah
Setelah data subjek/objek dan batas bidang terkumpul kemudian dilakukan digitasi bidang tanah hasil dari pemetaan partisipatif dan entry attribute untuk pendataan bidang tanah tersebut pada ArcGIS 10.5. Sehingga dihasilkan Peta Informasi Bidang Tanah (PIBT).

8. Analisa Hasil dan Kesimpulan

Pada tahap ini dilakukan analisa mengenai pembuatan peta orthophoto hingga pembuatan peta informasi bidang tanah. Setelah analisa didapatkan, maka akan ditarik kesimpulan mengenai pembuatan peta informasi bidang tanah ini.

\section{HASIL DAN PEMBAHASAN}

1. Pembuatan Jalur Terbang

Pembuatan jalur terbang menggunakan aplikasi pix4d. Pembuatan jalur terbang ini yaitu untuk merencanakan jalur terbang Wahana QuadCopter sehingga didapatkan hasil foto sesuai yang direncanakan. Disini Wahana QuadCopter terbang dengan ketinggian 150 meter diatas lokasi penelitian seluas 259,335 hektar. Total foto yang dihasilkan 1803 buah yang terbagi atas 17 misi penerbangan.

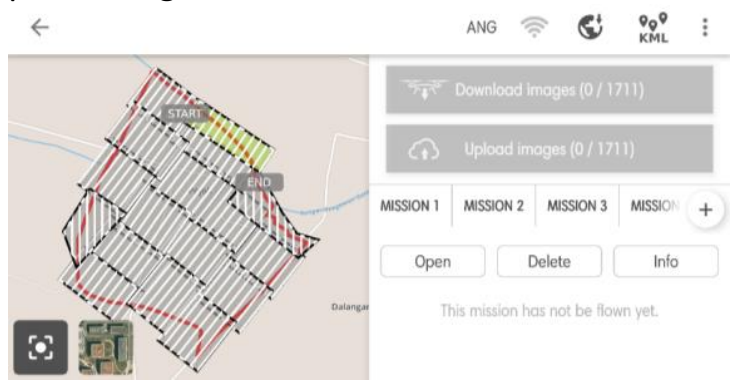

Gambar 2. Perencanaan Jalur Terbang Drone Menggunakan Software Pix4d

2. Hasil Pengukuran GCP dan ICP

Pengukuran Ground Control Point (GCP) dilakukan pada 10 titik yang tersebar di Desa Pojok. Pengukuran GCP ini menggunakan GPS Geodetik dengan metode statik. Pada pengukuran ini base yang digunakan adalah CORS Solo (CSLO). Durasi tiap sesi pengamatan dilakukan selama \pm 30 menit. Data yang digunakan dalam penelitian ini yaitu data koordinat planimetris $(X, Y)$. Berikut merupakan persebaran titik-titik GCP: 


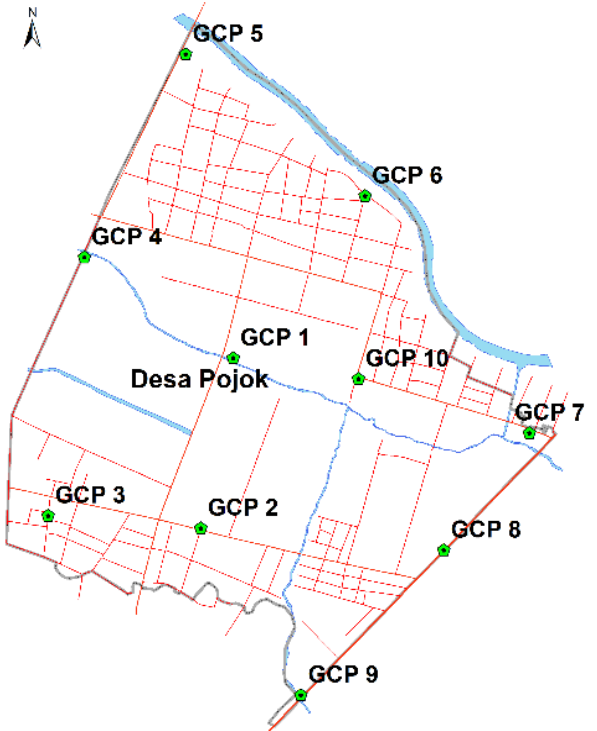

Gambar 3. Persebaran Titik GCP

Tabel 1. Koordinat GCP Hasil Pengukuran Lapangan

\begin{tabular}{llll}
$\begin{array}{l}\text { Nama } \\
\text { Titik }\end{array}$ & $\mathbf{X}(\mathbf{m})$ & $\mathbf{Y}(\mathbf{m})$ & $\mathbf{Z}(\mathbf{m})$ \\
\hline \hline GCP 1 & 477759,098 & 9147021,460 & 252,109 \\
GCP 2 & 477642,115 & 9146406,279 & 252,742 \\
GCP 3 & 477091,240 & 9146451,431 & 251,201 \\
GCP 4 & 477222,128 & 9147386,550 & 251,988 \\
GCP 5 & 477587,362 & 9148120,915 & 252,048 \\
GCP 6 & 478234,282 & 9147608,023 & 253,105 \\
GCP 7 & 478826,127 & 9146750,648 & 253,370 \\
GCP 8 & 478517,809 & 9146326,269 & 253,638 \\
GCP 9 & 478002,789 & 9145801,849 & 254,454 \\
GCP 10 & 478210,497 & 9146946,437 & 253,297 \\
\hline
\end{tabular}

Nilai Standar Deviasi Pengukuran GCP

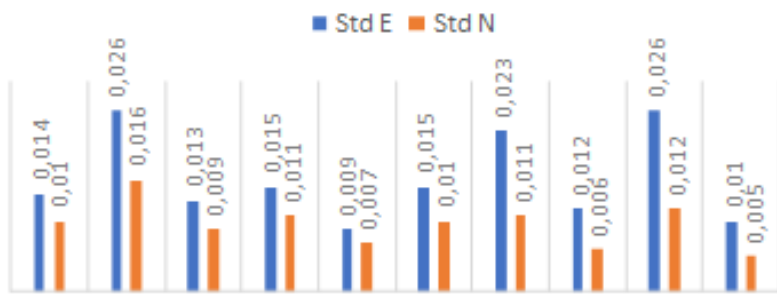

GCP 1 GCP 2 GCP 3 GCP 4 GCP5 GCP 6 GCP 7 GCP 8 GCP 9 CP 10

Gambar 4. Standar Deviasi Koordinat Titik GCP

Dari gambar 4 tersebut dapat diketahui bahwa nilai standar deviasi terbesar yaitu pada GCP 2 dan GCP 9 dengan nilai sebesar 0,026 dan nilai standar deviasi terkecil yaitu pada GCP 10 dengan nilai sebesar 0,005.
Tabel 2. Koordinat ICP Hasil Pengukuran Lapangan

\begin{tabular}{llll}
\hline $\begin{array}{l}\text { Nama } \\
\text { Titik }\end{array}$ & $\mathbf{X}(\mathbf{m})$ & $\mathbf{Y}(\mathbf{m})$ & $\mathbf{Z}(\mathbf{m})$ \\
\hline \hline ICP 1 & 478223,940 & 9146457,818 & 252,086 \\
ICP 2 & 477747,945 & 9146380,015 & 251,671 \\
ICP 3 & 477604,018 & 9146734,652 & 250,745 \\
ICP 4 & 477497,604 & 9146439,673 & 252,862 \\
ICP 5 & 477040,594 & 9146981,802 & 249,942 \\
ICP 6 & 477429,400 & 9147819,043 & 251,623 \\
ICP 7 & 477920,798 & 9147861,861 & 252,571 \\
ICP 8 & 477819,985 & 9147379,387 & 252,583 \\
ICP 9 & 478192,517 & 9147278,285 & 252,374 \\
ICP 10 & 478486,568 & 9146873,775 & 252,465 \\
ICP 11 & 478645,615 & 9146475,274 & 253,183 \\
ICP 12 & 478268,696 & 9146114,914 & 253,176 \\
\hline
\end{tabular}

Nilai Standar Deviasi Pengukuran ICP $\because \operatorname{Std} \mathrm{E} \backsim \operatorname{Std} \mathrm{N}$

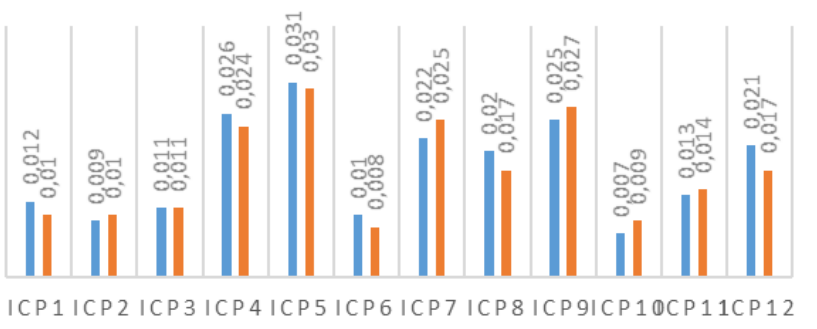

Gambar 5. Standar Deviasi Koordinat Titik ICP

Dari gambar 5 tersebut dapat diketahui bahwa nilai standar deviasi terbesar yaitu pada ICP 5 dengan nilai sebesar 0,031 dan nilai standar deviasi terkecil yaitu pada ICP 10 dengan nilai sebesar 0,007 .

Data koordinat dari GCP yang berjumlah 10 titik tersebut digunakan dalam proses georefencing pada model foto, sedangkan untuk data koordinat ICP yang berjumlah 12 titik tersebut akan digunakan sebagai titik pembanding dalam proses uji akurasi planimetrik.

3. Georeferencing

Pada proses ini yaitu memberikan koordinat hasil pengukuran kedalam model yang masih berkoordinat foto.

Tabel 3. RMS Error Pergeseran Pada Proses Georeferencing

\begin{tabular}{llllll}
\hline $\begin{array}{l}\text { Nam } \\
\text { a }\end{array}$ & $\begin{array}{l}\mathbf{X} \\
\text { error } \\
\mathbf{( c m})\end{array}$ & $\begin{array}{l}\text { Y } \\
\text { error } \\
\mathbf{( c m})\end{array}$ & $\begin{array}{l}\text { Z } \\
\text { error } \\
\mathbf{( c m})\end{array}$ & $\begin{array}{l}\text { Total } \\
\mathbf{( c m )}\end{array}$ & $\begin{array}{c}\text { Image } \\
\text { (pix) }\end{array}$ \\
\hline \hline GCP 1 & 0,878 & $-0,459$ & $-1,178$ & 1,539 & $0,961(26)$ \\
GCP 2 & $-4,619$ & 1,561 & $-2,639$ & 5,544 & $0,772(3)$ \\
GCP 3 & $-0,276$ & $-3,148$ & $-0,617$ & 3,220 & $0,942(12)$ \\
\hline
\end{tabular}




\begin{tabular}{llllll}
\hline $\begin{array}{l}\text { Nam } \\
\mathbf{a}\end{array}$ & $\begin{array}{l}\mathbf{X} \\
\text { error } \\
\mathbf{( c m})\end{array}$ & $\begin{array}{l}\mathbf{Y} \\
\text { error } \\
\mathbf{( c m )}\end{array}$ & $\begin{array}{l}\mathbf{Z} \\
\text { error } \\
\mathbf{( c m})\end{array}$ & $\begin{array}{l}\text { Total } \\
\mathbf{( c m )}\end{array}$ & $\begin{array}{c}\text { Image } \\
\text { (pix) }\end{array}$ \\
\hline \hline GCP 4 & 2,505 & $-3,104$ & 4,217 & 5,805 & $0,983(10)$ \\
GCP 5 & 3,294 & $-3,109$ & 2,710 & 5,309 & $0,988(20)$ \\
GCP 6 & 2,619 & 3,738 & 2,711 & 5,309 & $0,988(20)$ \\
GCP 7 & 2,469 & 3,716 & $-0,151$ & 4,464 & $0,996(36)$ \\
GCP 8 & $-1,976$ & 2,226 & 1,732 & 3,444 & $0,888(24)$ \\
GCP 9 & $-3,197$ & $-0,599$ & 1,895 & 3,765 & $0,991(17)$ \\
GCP & $-2,631$ & 3,085 & $-5,537$ & 6,862 & $0,978(21)$ \\
10 & & & & & \\
\hline Total & $\mathbf{2 , 7 0 8}$ & $\mathbf{2 , 7 2 9}$ & $\mathbf{2 , 8 0 8}$ & $\mathbf{4 , 7 6 1}$ & $\mathbf{0 , 9 3 6}$ \\
\hline \hline
\end{tabular}

Dari tabel 3 diatas menunjukkan bahwa RMSE titik kontrol terbesar di titik GCP 10 sebesar $6,862 \mathrm{~cm}$ dan RMSE titik kontrol terkecil yaitu pada titik GCP 1 sebesar $1,539 \mathrm{~cm}$.

4. Hasil Orthophoto

Pembentukan orthophoto yaitu melalui beberapa tahap, seperti: Alignment Photo, pembentukan Dense Cloud, pembentukan Mesh, pembentukan Texture, serta Orthomosaik. Berikut merupakan hasil orthophoto Desa Pojok, Kecamatan Tawangsari, Kabupaten Sukoharjo:

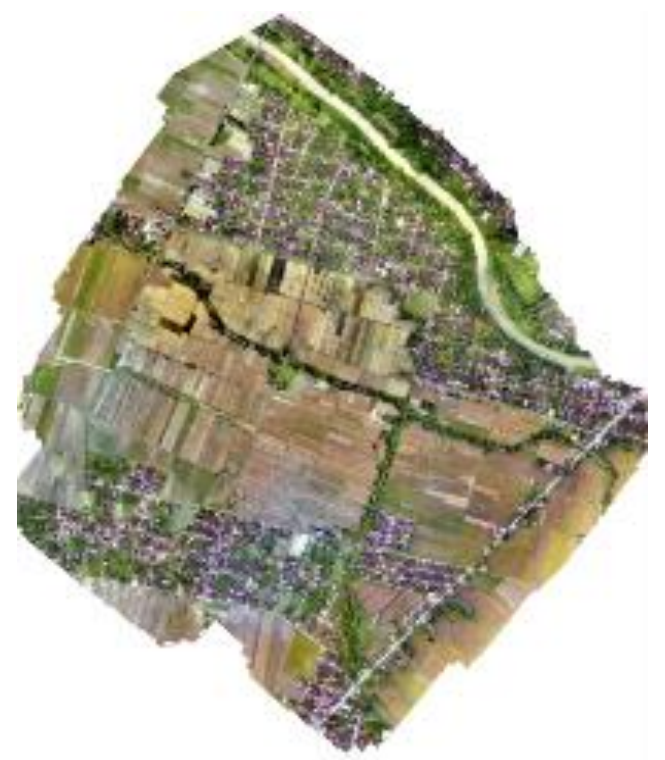

Gambar 6. Hasil Orthophoto

5. Koordinat ICP Model dan Lapangan

Independent Check Point (ICP) digunakan dalam pengujian akurasi dari Ground Control Point (GCP). Uji akurasi ini didapatkan dari selisih koordinat ICP Model dengan koordinat ICP lapangan. Selisih terbesar pada koordinat $X$ yaitu di titik ICP 6 sebesar $-0,631 \mathrm{~m}$ dan pada koordinat $Y$ yaitu di titik ICP 3 sebesar $0,577 \mathrm{~m}$.

Tabel 3. Koordinat ICP Model dan Koordinat ICP Lapangan

\begin{tabular}{llllll}
\hline Nama & \multicolumn{2}{l}{ Koordinat ICP Model } & Nama & \multicolumn{2}{l}{ Koordinat ICP Lapangan } \\
& $\mathbf{X}(\mathbf{m})$ & $\mathbf{Y}(\mathbf{m})$ & & $\mathbf{X}(\mathbf{m})$ & $\mathbf{Y}(\mathbf{m})$ \\
\hline \hline ICP 1 & 478223,953 & 9146457,798 & ICP 1 & 478223,940 & 9146457,818 \\
ICP 2 & 477747,997 & 9146380,053 & ICP 2 & 477747,945 & 9146380,015 \\
ICP 3 & 477604,002 & 9146734,644 & ICP 3 & 477604,018 & 9146734,652 \\
ICP 4 & 477497,684 & 9146439,569 & ICP 4 & 477497,604 & 9146439,673 \\
ICP 5 & 477040,482 & 9146981,715 & ICP 5 & 477040,594 & 9146981,802 \\
ICP 6 & 477429,466 & 9147818,946 & ICP 6 & 477429,400 & 9147819,043 \\
ICP 7 & 477920,741 & 9147861,961 & ICP 7 & 477920,798 & 9147861,861 \\
ICP 8 & 477820,095 & 9147379,429 & ICP 8 & 477819,985 & 9147379,387 \\
ICP 9 & 478192,639 & 9147278,202 & ICP 9 & 478192,517 & 9147278,285 \\
\hline ICP & 478486,586 & 9146873,815 & ICP & 478486,568 & 9146873,775 \\
10 & & & 10 & & \\
ICP & 478645,598 & 9146475,372 & ICP & 478645,615 & 9146475,274 \\
11 & & & 11 & & \\
ICP & 478268,743 & 9146114,888 & ICP & 478268,696 & 9146114,914 \\
12 & & & 12 & & \\
\hline
\end{tabular}

6. Uji Akurasi Planimetrik

Untuk melakukan uji akurasi planimetrik, hasil selisih tiap koordinat ICP model dengan ICP lapangan kemudian dihitung RMSEr dengan rumus:

$R M S E r=\sqrt{\frac{\sum D\left(X_{\text {model }}-X_{\text {Lapangan }}\right)^{2}+\sum D\left(Y_{\text {model }}-Y_{\text {Lapangan }}\right)^{2}}{n}}(1)$

RMSEr = Root Mean Square Error pada posisi $\mathrm{x}$ dan y (horizontal)

$\mathrm{n}=$ jumlah total pengecekan pada peta

$\mathrm{D}=$ selisih koordinat yang diukur dilapangan dengan di peta

$x=$ nilai koordinat pada sumbu $X$

$y=$ nilai koordinat pada sumbu $Y$

Dari perhitungan tersebut didapatkan nilai RMSEr sebesar 0,099901 meter. Standar akurasi menurut NMAS (National Map Accuracy Standar) adalah sebagai berikut:

Akurasi Horisontal NMAS $=1,5175 *$ RMSEr (2)

Sehingga dihasilkan nilai sebesar 0,151599 meter untuk uji akurasi horisontal. Kemudian dilakukan pengujian terhadap hasil tersebut sebagai berikut: 
Tabel 5. Tabel Uji CE90 untuk Ketelitian Peta Skala $1: 1000^{[1]}$

\begin{tabular}{|l|l|l|l|l|}
\hline Ketelitian & Hasil Uji & \multicolumn{3}{|l|}{ Ketelitian Peta Skala 1:1000 } \\
\cline { 3 - 5 } & $\begin{array}{l}\text { CE90 } \\
(\mathrm{m})\end{array}$ & Kelas I & Kelas II & Kelas III \\
\hline Horisontal & 0,152 & 0,2 & 0,3 & 0,5 \\
\hline
\end{tabular}

7. Pengumpulan Subjek/Objek dan Validasi Batas Bidang Tanah Melalui Partisipasi Masyarakat

Pengumpulan subjek/objek bidang tanah serta validasinya atau biasa disebut pemetaan partisipatif disini langsung dilakukan dengan masyarakat diatas hardcopy peta dasar orthophoto yang telah didapatkan dari proses sebelumnya. Pada pengumpulan data ini untuk areal persawahan informasi subjek/objek bidang tanah serta validasinya didapatkan melalui kelompok-kelompok tani. Untuk daerah pemukiman informasi subjek/objek bidang tanah serta validasinya didapatkan melalui masyarakat setempat dan perangkat desa setempat.

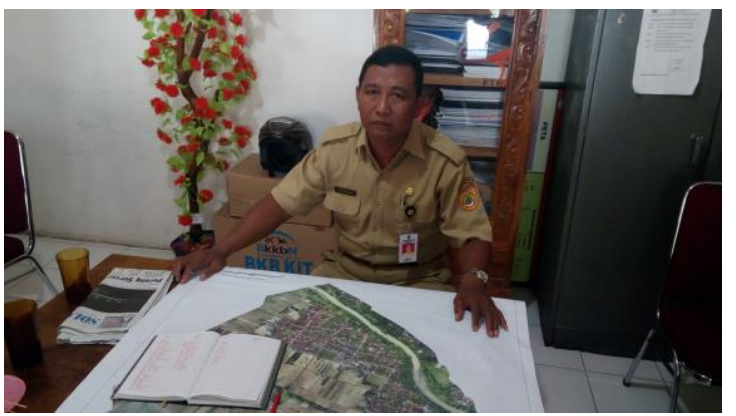

Gambar 7. Pemetaan Partisipatif dengan Perangkat Desa

Pada gambar 7 diatas, dalam pengumpulan data pertanahan berupa subjek/objek bidang tanah serta validasi batasnya dilakukan dengan perangkat Desa Pojok.

8. Digitasi dan Pembuatan Peta Informasi Bidang Tanah

Digitasi dilakukan pada software ArcGIS 10.5. Pada desa penelitian, secara umum daerahnya hanya terbagi atas daerah pemukiman dengan total bidang 1.443 bidang dan areal persawahan dengan total bidang 615 bidang.

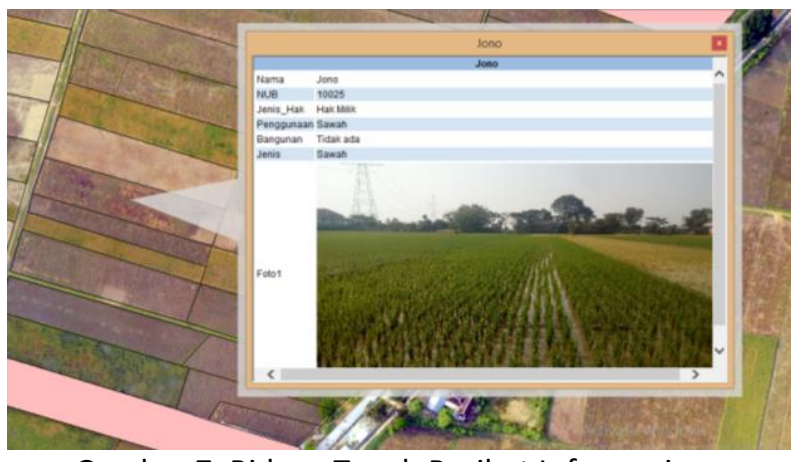

Gambar 7. Bidang Tanah Berikut Informasinya

Dari gambar 7 diatas dapat diketahui mengenai informasi dari bidang tanah tersebut. Informasinya berupa nama pemilik, NUB (Nomor Urut Bidang), Jenis Hak, Penggunaan bidang, kondisi bidang (terdapat bangunan atau tidak), jenis bidang (sawah/pekarangan/kebun) serta foto kondisi lokasi bidang tersebut.

\section{KESIMPULAN}

1) Telah dibuat peta dari hasil pemotretan udara menggunakan wahana quadcopter / drone sebagai peta dasar dalam pembuatan peta informasi bidang tanah (PIBT) yang memiliki nilai RMS Error pergeseran pada proses georeferencing sebesar 4,671 cm. Untuk uji akurasi planimetrik dihasilkan RMSEr sebesar 0,099 m sehingga ketelitian horisontal (CE90) peta dasar skala 1:1000 pada kelas 1 .

2) Pengumpulan data untuk mendapatkan subjek/objek bidang tanah dan validasinya melibatkan partisipasi dari masyarakat, baik perangkat desa maupun warga setempat.

3) Peta Informasi Bidang Tanah (PIBT) yang telah dibuat didominasi oleh areal persawahan dengan total luas 128,597 hektar yang terdiri dari bidang tanah sebanyak 615 bidang dan daerah pemukiman dengan total luas 69,378 hektar yang terdiri dari 1.443 bidang.

\section{UCAPAN TERIMA KASIH}

Penulis A.W.W mengucapkan terimakasih kepada perangkat desa dan warga Desa Pojok, Kecamatan Tawangsari, Kabupaten Sukoharjo yang telah membantu dalam identifikasi hingga deliniasi bidang tanah di lokasi. 


\section{DAFTAR PUSTAKA}

Indonesia, Badan Informasi Geospasial (BIG). 2014. Peraturan Kepala Badan Informasi Geospasial Tentang Pedoman Teknis Ketelitian Peta Dasar. Bogor: Badan Informasi Geospasial (BIG).

Indonesia, Badan Pusat Statistik (BPS). 2017. Kecamatan Tawangsari Dalam Angka 2017. Sukoharjo: Badan Pusat Statistik Sukoharjo.

Indonesia, Direktur Jenderal Infrastruktur Keagrariaan. 2017. Petunjuk Teknis Pembuatan Peta Informasi Bidang Tanah Melalui Partisipasi Masyarakat. Jakarta: Direktur Jenderal
Infrastruktur Keagrariaan

Indonesia, Kementerian ATR/BPN. 2016. Petunjuk Teknis Pengukuran Dan Pemetaan Bidang Tanah Sistematik Lengkap. Jakarta: Kementerian ATR/BPN

Ramadhiani, Arimbi. 2016. Catat, Baru 45 Juta Bidang Tanah di Indonesia yang Telah Bersertifikat,<URL:http://properti.kompas.co m/read/2016/10/09/160000321/catat.baru.45 .juta.bidang.tanah.di.indonesia.yang.telah.ber sertifikat>. Dikunjungi pada tanggal 12 Januari 2018 jam 21.00 WIB.

\section{Lampiran :}

Berikut merupakan Peta Informasi Bidang Tanah untuk Desa Pojok RT 3 RW 2, Kecamatan Tawangsari, Kabupaten Sukoharjo:

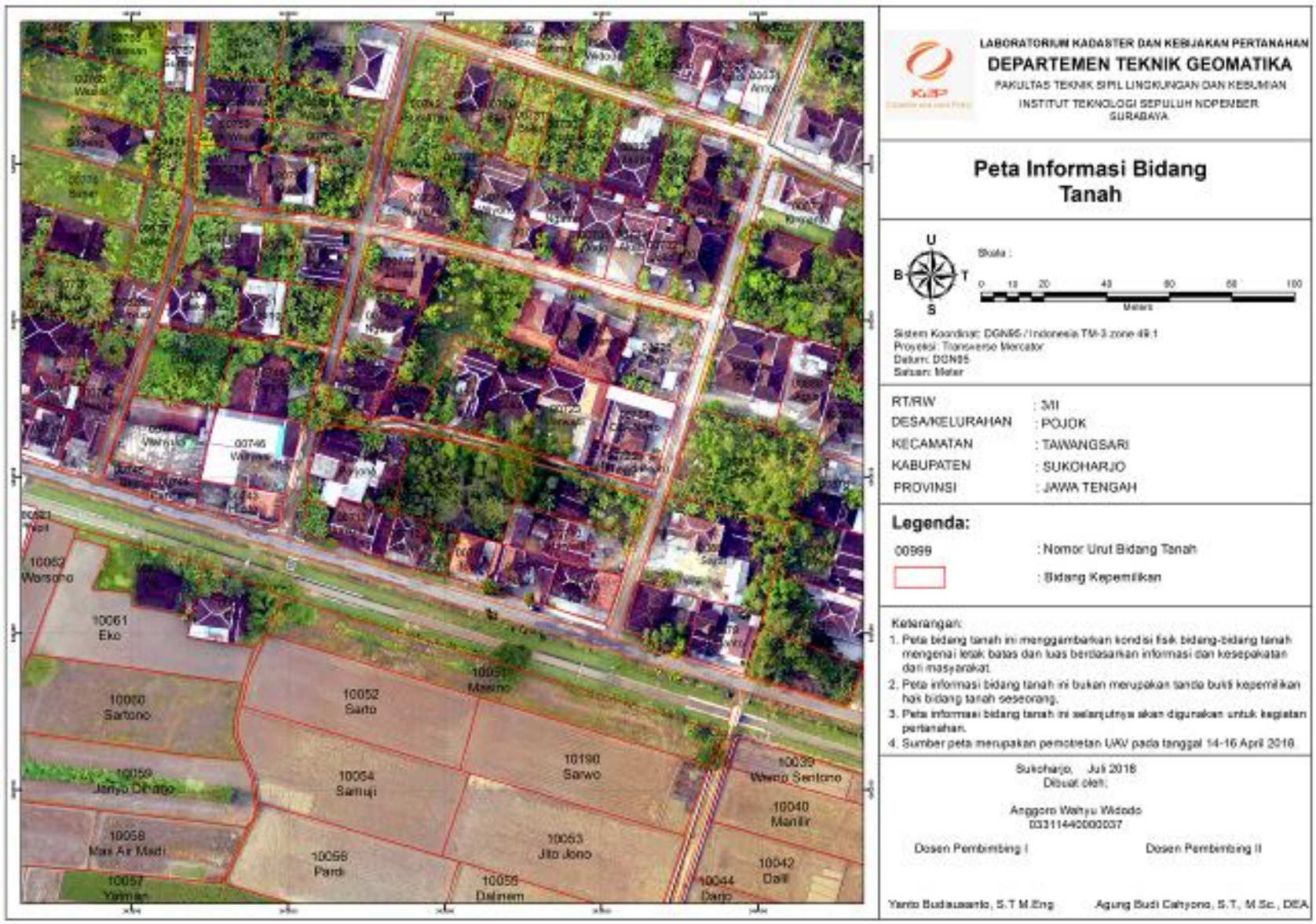

